coneretions cicatrices, etc., is very generally associnted with ceondary disease of the heart; while advancing tubercle has no appreciable influence (or rather, is frequently the cause of candiac atrophy)".

The hypertrophy of the walls of the heart is held to be cocondary to the diatation of its carities in connecoion with which a very remarkable circumstance presents itself in Dr. Chambers's Table, - viz.: The large propurtion of cases of tuberculosis in which dilatation alone was noted,viz.:9.2 per cent. ; which of hypertrophy alone, and of dilatation with hypertrophy, there were respectively only 2.9 and 2.5 per cent., seeming to indicate that the atrophied walls of the heart of tuberculous subjects are prone to give way to any extra-dilating force, but the direct debility which accompanies that atrophy is unfarourable to the increased action which results in hypertrophy.

Those who take an interest in this department of pathology, will recognize in this lengthy communication new facts and reasonings of considerable importance to the elucidation of some of the dubious points in the history of this disease, and the tendency of these statistics appears to be, to establish, as a general principle, that while a tuberculous condition of the blood is to a very great extent unfarourable to the development of some other constitutional diseases; these same diseases are extremely prone to merge into or become complicated with, and to terminate in tuberculosis.

Norfolk Crescent, Hyde Park Square, Jan. 1851.

\section{FACTS CONTRIBUTED TO THE PATHOLOGY OF DRY GANGRENE.}

\section{By JOSEPH SAMPSON GAMGEE, Esq.}

MUсH as this disease has been studied by surgical pathologists, since Mr. Percivall Pott first attracted prominent notice to it, "professional opinion is still unsettled as to its cruse"."

Baron Dupuytren referred it to arteritis.t His opinions and observations were characterized as inconclusive and defective by Sir Robert Carswell, who maintained $\ddagger$ that calcification of the arterial coats and occlusion of the vessels is the cruse of the disease, and that there was no evidence of idiopathic inflammation of the large arteries giving rise to it. His criticism has the assent of Sir B. Brodie, who is certain that "M. Dupuytren is mistaken on this point". \$ And if Mr. Liston, $\|$ in whose opinion the Baron's attempt to connect mortification with an inflamed state of the arterial coats is not confirmed by experience. Professor Linoli $T$ held a medium view ; that arterial ossification is the remote, and inflammation the proximate cause. Professor Velpeau** expresses himself dissatisfied with the state of knowledge on this disease, and cites several cases of it in which he was unable to discover any anatomical change whatever to account for the phenomena. Many other instances of dissenting opinions might be quoted, not only with reference to the pathology, but also to the treatment of the disease ; but enough has, I think, been adduced to demonstrate the desirability of adding facts which are calculated to exercise an influence in the solution of the question.

Casz I. Gaspera Innocenti, aged 62, was admitted into the female clinical ward of Santa Maria Nuova, Florence, under Professor Ranzi, on the 30th of September, 1851, when the following notes were taken by me. She is a

- Mr. Syme, Contributions to the Pathology and Practice of Surgery. Edinburgh: 1848. p. 9.

+ Lecons Orales de Clinique Chirurgicale. $2 d$ ed., t. iii, p. 268.

Illustrations of the Elementary Forms of Disesse. Article "Mortifcention".

Leetures Ilustrative of Various Subjects in Pathology and Surgery, 1846, p. 850.

II Elements of Surgery. By Robert Liston. $2 d$ ed., p. 42.

Teso di Gangrena secca con Autopsia Cadaverica del Prof. Linoli, negi Annali Univeraeli di Medicina, compilati da Annibale Amadei, $t$ lxiv,

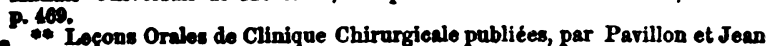

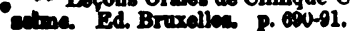

peasant from the Appennines, accustomed to live on bread, beans, chesnuts, and weak wine; only eats meat twice or three times in the year. About sixteen days ago, she experienced severe burning pain in the whole of the left hand, from the wrists to the ends of the fingers; the latter acquired a black colour in the course of four or five days, and the gangrene has ever since gradually extended.

The pulse is very visible in both carotids, 120 in the minute. Pulsation is distinct in the outer side of the right subclavium, not so in the left. The arteries of the right arm and forearm pulsate well. Those on the left side cannot be felt. The left posterior tibial artery pulsates indistinctly, the right one does not do so at all. The same remark applies to the dorsal arteries of the feet. Both lower limbs as far up as the knees are œdematous.

The fingers of the left hand are semi-flexed. cold, motionless, senseless, black, and somewhat shrivelled; this condition involves the whole hand as far as the wrist.

The following temperatures are ascertained with the centigrade thermometer, care being taken that all the parts are similarly circumstanced as to covering :-

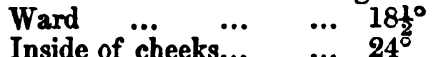

$$
\begin{aligned}
& \text { Both arm pits ... ... } 24^{\circ} \\
& \text { Bend of elbow ... } \begin{cases}\text { left } & 21^{\circ}\end{cases} \\
& \text { Palm of hand } \ldots \begin{cases}\text { right } & 23^{\circ} \\
\text { left } & 20^{\circ} \\
\text { right } 23^{\circ}\end{cases} \\
& \text { Dorsum of foot ... } \begin{cases}\text { left } & 22^{\circ} \\
\text { right } & 20^{\circ}\end{cases}
\end{aligned}
$$

Strength gradually diminished ; the gangrene extended a little up the forearm, but did not appear in any other part of the body ; death occurred at 7 p.m. on the 7th October. Treatment adopted was bark and opium, with tolerably good diet.

Examination forty hours after decth. The abdomen contains about two pints of turbid greenish fluid, with flocculi of lymph floating in it. The viscera of this cavity are healthy.

About one pint and a half of limped serosity in the chest; lungs healthy; heart small and flaceid ; orifices: healthy; with the exception of some calcareous deposit at the insertion of the aortic semilunar valves.

Atheromatous degeneration manifest in the arch and descending portion of the aorta, especially around the orifices of the intercostal arteries. There is one patch of calcareous degeneration near the origin of the subclavian artery, and another above the origin of the cœliac axis. Firmly adhering to the last one, is the lower half of a blood clot measuring 23 inches in length, $\frac{1}{2}$ an inch in breadth, and a little more than a line in thickness; the upper half of the clot is loose, of dark red colour and rather soft; but the lower half is adherent, of reddish yellow colour, and firm.

The right common and external iliac arteries are almost completely obliterated by a blood clot, the upper half of which is of darkened colour, more uniform shape, and softer consistence than the lower half. The middle portion of the clot, including some of the dark red and soft, and some of the light red and consistent, is firmly adherent to the arterial coats, which appear healthy. A fine clot is contiuued into the right external iliac for rather more than an inch.

The left subelavian artery is decidedly redder than are the other great vessels springing from the aortic arch: on careful examination, the redness is seen to be due to capillary injection; this is most marked along the concavity of the artery. This injection extends as far as five inches beyond the origin of the superior intercostal; as far as this point the colour of the arterial coats is deep red ; beyond it, they are of normal colour, but very much contracted. On comparing the brachial radial and ulnar arteries of the two sides, those on the left prove to be decidedly the smallest.

On slitting open the left subclavian artery from its commencement onwards, an obliterating clot seven inches in 
Inth is exposed. At its proximate extreenity, the dot is af dark red colour, smooth on the surface, nom-edberent, of modernte consistence ; a little further on, it is softer, especisll near the surface.

Towards its distal extremity, it regains consistence, scquires a lighter colour, and is 80 firmly adherent to the artery, that on attempting to detach it, it breaks up. Just bejond the congulum, the artery contains a whitish, rather dry, grumous substance, which adheres to, but admits of being detached from, the artery. Under the microscope it is found to consist of imperfect granular and pus corpuscles.

It is to be regretted that I did not take more copious notes of negative characters, especially as to the absence of calcific degeneration in particular vessels. I distinctly remember that there was no notable calcification in the arteries of the affected upper limbs, in accordance with the well-known fact, that, frequent as this change is in the aorta and its inferior ramifications, it is uncommon in the subclavisn and brachial arteries and their divisions. The satomical characters observed on dissection of the left upper limb prove that inflammation, and consequent occlusion of its arteries by plastic deposit, was the cause of the mortification in this case.

Facts very similar to those above recorded have been observed once in the upper limb by M. Chassaignac,* and thus the occasional sequential relation of arteritis and dry gangrene no longer admits of doubt.t. It must, however, be admitted, that in the majority of instances of dry gangrene in which the arterial system has been dissected, no inflammation has been discovered, but the arteries have been found obliterated in consequence of atheromatous and calcific degeneration of their coats.

The rarity of calcification in the arteries of the upper limb, the very small number of well attested cases of dry gangrene following arteritis, and the fact that in my case, and in the one recorded by $M$. Chassaignac, of dry gangrene symptomatic of arteritis, the disease affected the upper limb, are facts which simultaneously strike one as bearing relation to each other. What the nature or degree of intimacy of this relation may be, future observations will determine.

Cage Ir. Marianna Cerchi, aged 85, admitted under Professor Reguolo, into No. 269 in the female clinical ward of Santa Maria Nuova, Florence, on the 10th February, 1852. Her mental faculties being somewhat impaired, she is unable to give a detailed history of her disease ; but is positive that the gangrenous foot has never been black, but has on the contrary preserved its natural white colour.

On admission, the right foot was of dirty white colour, shrivelled up and hard, almost completely separated from the leg at the ankle joint by the effort of nature.

18th February. The foot was removed on the joth by cutting through a piece of skin at the anterior part of the ankle, it being the only remaining bond of union between the foot and leg. The stump, which then looked red, has now a grey aspect. The immediate end of all the toes and of the left foot are black and horny. They may have been so several days, but no complaint having been made, attention has not been directed to the part. Since admission, the old woman has gradually grown weak and is to day moribund.

I made the post moriem examination on the 20th February, death having occurred on the 18 th, an hour after taking the foregoing report.

No rigor mortis; a good deal of tympanitis ; considerable odema of right thigh and leg; none of left lower limb, or of upper ones.

- Recherches sur la Gangrène Spontanée, appelée Gangrène séuile, par M. Chassaiguac. Mém. de la Soc. Chir. de Puris, vii, pp. 25t-278.

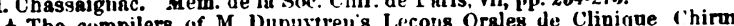
sicale, have silers of $\mathrm{M}$. Pre ganions relatively to "L In two of he cases (I and III) change in thes ( 1 and 111 . Case 11 , is one of sloughing of the scrotum and penis without known rcason, and certuin no wention is made of arteritis. Even the other facts aud arguments they have collectod are far from proving that arteritis is the cause of dry gangrene.
The cente dit throwghout its whole extons is focid to bo extemaively atheromatous, the doposit being comparatively limited to the neighbourhood of the mouths of resects which branch from the trunk. The acrtic conts hare mdergone the calcific degeneration at three differant spote, esch in the vicinity of the point where the left subcla rian, cooliac axis, and inferior mesenteric are given off.

Innominate and common carotids with their branches on both sides notably atheromatous, but only one small point of calcification on each side; on the right it is situated at the bifurcation of the innominata, and on the left at the bifurcation of the common carotid.

Atheroma, but no calcification; in subclavian axillary and brachial arteries on both sides. In the last named, it diminishes with the incresse of distance from the heart. Both radial and ulnar arteries perfectly healthy.

Atheroma and calcification in both common iliacs; the former, but not the latter, degeneration exists in both external and in the left internal iliacs. Right internal iliac healthy.

In dissecting the femoral ressels on the left side, nothing peculiar is seen externally. 1 good deal of atheromatous degeneration discovered on laying open the left common femoral, and also a small calcareous patch an inch above the origin of the profunda, which on being slit up proves to be perfectly healthy. There is slight atheromatous dogeneration in the upper inch and a half of the left superticial femoral, but none in the remainder of its extent. On laying open the left popliteal artery, numerous calcareous patches discovered in different parts of it.

The upper portion of the artery is obliterated by a red blood clot, but lower down by a firm white clot which extends down into the upper two-thirds of the posterior tibial ; the remainder of this vessel is pervious. The corresponding anterior tibial pervious and healthy. The peroneal and plantars not examined.

RIGHT LOWER LIMB. Arteries. Unusual difficulty is experienced in dissecting the femorals, owing to adhesions between them and the adjacent tissues. There is a marked vascular network in the cellular cost covering the common and superficial femorals in their whole extent. Its meshes are not very close, but of bright red colour. On removing the cellular coat, the artery remains pale. This red net work contrasts strongly with the external pallor of the left femoral. On slitting open the common femoral artery, no atheroma, but just above the origin of the profunda it presents a rectangular calcareous patch mean suring a quarter by half an inch. In the superficial femoral is a little atherome just below the origin of the profunda, and a small patch of it on the posterior wall of the ressel just about its middle. Deep femoral artery healthy.

Right popliteal artery contains numerous calcareous patches in its coats; at about its middle the whole circumference of the artery is calcified. Corresponding to this spot, the artery is partially cccluded by a firm adherent whitish clot. In dissecting this artery, I have found it decidedly more adherent than usual to the surrounding tissues. On its exterior, which looks white, are more rasa vasorum than usual.

Anterior tibial artery healthy. It is pervious except in its last inch, where it is occluded by white adherent clots (this is the side from which the foot separated). Peroneal artery healthy. Posterior tibial looks normal externally, but on cutting it open it contains a whitish firm cord. On cutting this cord across, it proves to be hollow. On slitting it open longitudinally, its interior is found lined by the inner coat of the artery. On eramining the exterior of the cord, atheroma (proved microscopically to consist of fat and cholesterine), is seen in it. This examination, carefully conducted, proved to me that the cord was due to longitudinal splitting up of the middle coat of the artery, contraction of the inner part of the said coat, including the lining membrane, 80 as to form a cylinder which appeared in the carity of the artery ; but what was at first taken to be the whole artery, prored to bo 
athing more than the outer cant with a part of the middle cont lifing it.

Tenows syatem of the right lonorr limbs. The common and internal iliac veins are perfectly healthy. On slitting up the external iliac vein, its costs are of normal colour and consistence; in its interior is a conically shaped non-adherent but consistent clot, extending from half an inch below the origin of the internal iliac down into the femoral rein.

On laying open the common and superficial femoral veins, which have a slate colour externally, with a fine network of very small vessels ramifying on them, I find their conts decidedly thickened throughout, but especially so the upper inch of the common femoral, where the tunics feel and cut almost like cartilage, and are very closely adherent to a firm reddish clot in the interior of the vein. This clot effectually closes the terminal orifice of the saphena. From the entrance of this vein downwards, the superficial femoral vein contains a clot which becomes irregularly smaller and less adherent as it descends. It ceases completely about its middle. Whereas, above the orifice of the saphena, the clot is quite dry, below it it is bathed by a fluid in colour and consistency very much like chocolate and milk. Below the part where the clot ends, the vein is filled with a fluid of this kind. Opposite the termination of the said clot the femoral is joined by a venous branch, on tracing which into the triceps extensor, its first part is found to contain more of the chocolate-like fluid, but further on it contains a fluid like good pus. On sponging this away the lining membrane remains rough, in consequence of white matter remaining adherent to it. On removing the fluid from the superficial femoral, its lining membrane presents a similar appearance. Both these reins are preternaturally red where the white puslike matter does not adhere to their inner coat.

The deep femoral vein at its upper part is occluded by an adherent clot, which becomes softer and acquires more the character of a healthy venous clot as it descends.

The muscles of the thigh are healthy.

The external and internal saphenous veins in the right leg are perfectly healthy; their orifices on the face of the stump are closed by adhesive matter.

The popliteal vein is of a purplish colour, with very close vascular network on its exterior, and is quite round and feels solid. On slitting it open, it is found completely excluded in its whole length by a firm adherent clot.

The anterior and posterior tibial veins are healthy. One of the peroneal veins is healthy. The other is occluded by a tolerably firm and slightly adherent clot.

REYARKS. This case is replete with pathological interest.

A few days before death small dry gangrenous patches were noticed at the extreme parts of the left toes; on cadareric inspection we found the corresponding popliteal artery extensively calcified and obliterated by a firm and in part white clot, extending into the upper two-thirds of the posterior tibial. The anterior tibial was pervious.

No arterial inflammation was met with in this limb, but atheromatous and calcific degeneration were characteristically developed. It is curious that the extent of arterial obliteration was out of proportion greater than the amount of dead tissue would have led one to anticipate. This disproportion has been noticed by others, but only Cruvelhier appears to have recognized its true pathological signifiance; we shall presently have to recur to this matter.

On dissecting the femoral and popliteal vessels of the right side, unusual difficulty was experienced, owing to their preternatural adhesion to the tissues immediately adjoining; that this was due to inflammatory plastic effusion, appears evident, when the marked development of the vace rasorum noticed on the femoral vessels is taken into sccount.

That inflammation was not of arterial but of venous origin results from the following considerations:- $a$, the network of the rass rasorum was more evident; its meshes were closer over the veins than on the arteries; $b$, the proper arterial tunics did not exhibit any gigns of inflammation, not was there any plastic effusion within them; $c$, the characters of phlebitis were typically well developed, 80 much so, that the diseses was evidently of sereral days duration, - an interesting fact, when it is borne in mind that in-spite of it the process of disjunctive absorption between the leg and dead foot proceeded actively, and at its consummation the stump looked red and tolerably healthy for nearly two days. In which set of ressels did disease first commence? Were the arteries first closed by simple blood clots, or the veins by inflammatory deposits and their consequences, or vice versa? The dry and shrivelled appearance of the foot dispels all doubt in this regard ; the arterial mischief must have had the priority ; it is well known that just as cdema is one of the characteristic signs of venous, diminished size is of arterial obstruction.

The right popliteal artery was very much calcified, and a small firm clot occupied the greater part of its bore, but did not completely obliterate it. Moreover, the anterior tibial and peroneal arteries were healthy: hence, though much impeded, the course of blood to the foot was not completely suspended; yet the whole foot died, singularly contrasting with the state of things in the opposite limb, where the foot gave very slight signs of suffering, though the main artery of the limb, the popliteal, was completely occluded by old firm white adherent clot. "Lisez les observations publiées sur la gangrène sénile," says Cruveilhier,* "vous n'en trourez pas deux qui se ressemblent sous le rapport de l'étendue de l'obliteration des grosses artères. Ainsi, dans un cas présenté à la Société Anatomique par M. Maisonneuve, la fin de l'aorte, les deux artères iliaques primitives, iliaques internes et externes, poplitée, tibiale, et peronière, étaient complètement obliterées, et pourtant la gangrène était limitée à quelques orteils. Dans la deuxième observation que j'ai rapporté (xvii livraison, Anat. Patholog. du Corps Humain), l'obliteration était bornée aux artères tibiales postérieure et péronière; la tibiale antérieure était libre, et pourtant la gangrène avait envahi les quatres derniers orteils et la cóté externe de la jambe: comment se fait-il que l'artère tibiale antérieure étant libre, la circulation ne se soit pas rétablie dans les artères tibiale postérieure et peronière? Par une raison toute simple: c'est que les voies de commurication entre ces deux ordres de vaisseaux étaient interceptées par l'obliteration des collaterales." This is, I think, the only possible explanation; but be it remembered that it is matter of inference, not the result of direct observation. The condition of the smaller vessels has been singularly neglected by those who have studied this disease; and it remains to future pathologists to determine how often, and by what process, the small arterial ramifications are implicated. While admitting Cruveilhier's explanation of the disproportion between the extent of arterial disease and of gangrene, as the only possible one, I cannot subscribe to his generalisation, that "obliteration of the small arteries is the fundamental fact, as cause of spontaneous gangrene".t The facts to prove it are not at hand. In addition to the reasons above adduced, what renders it about certain that the main cause of gangrene in the right foot of Marianna Cerchi was obliteration of the ultimise arterial ramification, is the fact that the foot retained its normal colour. This would appear referrible to the complete exclusion of blood from the part, an exclusion so complete, that it can only be supposed possible as a result of closure of the smaller arteries; for, however completcly the trunks might be obliterated-but they were not so in this case-some blood would reach the part through collateral channels, and by its change impart the dark colour. $\neq$

* Traité d'Anat. l'ath. génér., t. ii, 18:52, p. 303 .

+ Op. cit., p. 302.

\$ In the Med. Chir. Trans., vol. xiii, is "a case of injury to the blood ressels of the lower cxtremity producin" pale dry rnugrene in the toot, by $T$. W. Chevallier. Fsq." At p.24, I find, "In concision, I may mention an observation of my father's, which I tiud contirmed in the writings of others, that the pule or white dry gangreue tukes place only where the veins of the parts affected are not obliterated." In ole cuse, however, tlie pale dry gangrene of the foot was associated with extensive obliteration of the veins of the same limb. 
Th condition in which I found the right pooterior tibial artery marits attention. On slitting it opon, it was found to contain \& whitish firm cord, which, on transverse section, proved to be hollow; and, when slit up longitudinally, its interior was found lined by the inner cost of the artery, and atheroms was deposited in its outer surface. Careful erremination proved that the cord was formed by longitudinal splitting up of the middle cost of the artery, and contraction of the inner part of the said cost, including the lining membrane, into a cylinder; and that it was not a olid body contained in the artery, as at first appeared, but in a shell formed by the outer coat, and most external layers of the middle one, which had preserved the original size and shape of the artery.*

The whitish firm cord had often been noticed by Carswell; but he did not examine its structure, and consequently misunderstood its nature. "In every case of gangrena senilis which I have examined after death (Carswell, op. cit.), the arteries of the limb were obliterated to such an extent as to interrupt the circulation of the blood. The obstructing cause existed in five or six cases of a fibrous tissue formed either in the valls or cavities of the arteries, and which had converted these vessels into nearly solid cords of ligamentous consistence." Carswell then recognised these cords as one of the most frequent causes of dry gangrene, acting as passive obstacles to the flow of arterial blood; but the discovery of this structure suggests future investigation to determine where they are not active agents. It is easy to conceive how, in the diseased condition of the middle coat (atheromatous degeneration), arterial contraction may be attended by its splitting up, and extreme contraction of its inherent part, so as to impede the access of blood.

The existence of arterial mischief in parts of the body where there was no external sign to indicate its existence (Case r), the disproportion between the extent of arterial obstruction and the outward manifestation of diseased cord where present (Case 1I), are weighty facts in connexion with the question of amputation in this disease. The very great majority of surgeons are agreed that, in spontaneous gangrene, amputation should not be performed until nature has made a decided effort to arrest the disease, and separate the dead part; the slow process of the completion of the line of demarcation may then be expedited by the operator's interference. Still there are surgeons who pursue an opposite line of practice; and $M$. Chassaignact concludes a commentary in a case of the kind, in which he amputated while the gangrene was spreading, by laying down as a rule, "that, where amputation is performed for senile gangrene, the knife should only be applied where the arterial pulsations are unmistakably felt". This may be a guaranteo that the stump will be supplied with blood, and not subject to mortification ; but it will certainly not lessen the chances of gangrene occurring in other parts. Theoretically, amputation is not indicated in this disease; for the dead part is but a symptom, which may certainly be removed; but

- These facts were noted sereral months before I became acquainted with These facts were noted sereral months before I became acquainted with published in the second volume of the Memoirs of the Parisian Society of published in the second volume of the Memoirs of the Parisian Society of pearances similar to those noted descr.bes, in all essential particulars, ap pearances similar to those noted ubove; but he appears to refer them to dis:ection; whereas there can be no doubt that the splitting up of the middle coat occurred during life. In point of fact, he says scarcely anything as to the probable mode of formation of these cords, and notling as to their pathoI ogical significance. In speaking of the arteries of the leg in case of dry gangrene, he says they were obliterated "par dos concrétions cretacées dures et sèches comme de la pierre et qui forment des cylindres parajssaut tamponner en quelque sorte la lumière du vaisseau. Ainsi en incisant de P'extérieur à l'intérieur, un semble ouvrir l'artère, dont on écarte les parcis. Fn les renversaut, et an centre de l'artère ainsi épunouie, ou voit le cylindre ossiforme, qui est parfaitement arrondi. Toutefois ce premier aspect est trompeur; ce n'est pas dans la cavité même du vaissesu que se trouve le cylindre, et la disposition que uous venons de signaler, $n$ 'est en quelque sort que le résultat meme de ha dissection, En effet, ce cylindre ossiforme, fendu suirant sou longueur, présente daus son axe une cavité évidemment tapissée par la son longuetur, presente dans son axe une cavite evidemment tapissee par la les plns externes de cernes plus inongainé dans les membranes djviseses, et qui au promier sopect parait fondu daos la cavite méme de l'artère."

+ Ytom. de la \$oc. de Chirurg. de Paris, loc. elt. the canso-arterial disense-is left in the gratem in full vigour, for the reproduction of the disease elesolvere. Though cases of successful amputation for dry gangreme are on record, the rule of abstinence is certainly borne out by the mass of experience, and particularly so by the two cases here reconded.

Both the patients whose histories I have related were very poor women-one an inhabitant of a secluded villago in the Appennines, whose life was certainly not devoted to the pleasures of the table; for milk and flour of chesnuts. were her staple articles of nourishment, and meat a luxury only about thrice a year indulged in. I have seen other three cases of this disease in persons of this class; and there seems good reason to suspect, contrary to the prevalent opinion, first sustained by Mr. Pott, * that this disease is scarcely if at all more frequent among the wealthy than the poorer classes.

Palazzo Corsi, Florence, January, 1854.

\section{COMPARATIVE FREQUENCY OF DISEASE OF} THE HEART AND EMPHYSEMA OF THE LUNG IN ST. GEORGE'S HOSPITAL AND THE EDINBURGH ROYAL INFIRMARY.

\author{
By THOS. K. CHAMBERS, M.D., Physician to \\ St. Mary's Hospital.
}

In the Association Medical Jodrusar for January 20, the attention of the profession was very properly drawn by Dr. Gairdner to the different results of certain statistics derived from the records of fatal cases at St. George's Hospital, London, published by me under the title of Decennium Pathologicum in the British and Foreign Medico-Chirurgical Review, and of those which he deduced from a similar source at the Edinburgh Infirmary, and which are the foundation of his admirable paper on emphysema published in the same periodical.

The chief differences are these:-

At St. George's, according to the records-

1. Cardiac disease appears to be somewhat more frequent than at the Edinburgh Infirmary.

2. Emphysema of the lung very much less frequent; vix., in the proportion of 12 to 31 .

3. The latter lesion appears to occur most often when the valves of the heart are diseased; whereas at Edinburgh it does not connect itself so much with valvular injury as with dilatation of the muscular walls.

The differences of material from whence the statistics are derived may be thus stated:-

Dr. Gairdner's statistics of the Edinburgh Infirmary are ninm Pathologicum are taken taken from the records of au- from the records of autopsiestopsies-

1. 84 in number.

2. Made with a special view to the observation of emphysema.

3. Conducted all by one hand.

4. From cases selected and known as clinically interesting: i.e. cases of chronic organic disease.

5. Made on the principle of omitting instances of endocardial or valvular lesion, judged not capable of causing functional disturbance.

The question which naturally presents itself, is, Which series of statistics shall we allow most to influence our opinions? In spite of the promptings of paternal affection I cannot feel justified in returning a simple categorical answer. For, in fact, each seems to me to possess recom- 